\section{Meliolaceae of Kerala, India - XXXI new species and a new variety}

\author{
V.B. Hosagoudar ${ }^{1} \&$ G.R. Archana ${ }^{2}$ \\ 1,2 Tropical Botanic Garden and Research Institute, Palode, \\ Thiruvananthapuram, Kerala 695562, India \\ Email: ${ }^{1}$ vbhosagoudar@rediffmail.com
}

\section{Asteridiella ixorae sp. nov.}

(Fig. 1)

\section{Material examined}

27.ix.2006, on leaves of Ixora sp. (Rubiaceae), Palode forest area, Thiruvananthapuram, Kerala, India, coll. V.B. Hosagoudar et al. HClO 48165 (type) TBGT 2901 (isotype), (MycoBank \# 518398 )

Coloniae amphigenae, subdensae, ad $2 \mathrm{~mm}$ diam., confluentes. Hyphae rectae vel subrectae, opposite acuteque vel laxe ramosae, laxe vel arte reticulatae, cellulae 12-30 $x$ 4-8 $\mu \mathrm{m}$. Appressoria alternata, unilateralis, 1\% opposita, antrorsa vel subantrorsa, recta, 12-22 $\mu \mathrm{m}$ longa; cellulae basilares cylindraceae vel cuneatae, 3-10 $\mu \mathrm{m}$ longae; cellulae apicales ovatae, oblongae, globosae, integrae vel leniter angularis, 8-13 x 8-11 $\mu \mathrm{m}$. Phialides appressoriis intermixtae, oppositae vel alternatae, ampulliformes, 12-22 x 6-8 $\mu \mathrm{m}$. Perithecia dispersa, globosa, ad $145 \mu \mathrm{m}$; cellulae peritheciales mammiformes, ad apicem obtusae, ad $10 \mu \mathrm{m}$ longae; ascosporae obovoideae, 4-septatae, constrictus ad septatae, 35-42 x 12-18 $\mu \mathrm{m}$.

Colonies amphigenous, subdense, up to $2 \mathrm{~mm}$ in diameter, confluent. Hyphae straight to substraight,

Date of publication (online): 26 May 2010

Date of publication (print): 26 May 2010

ISSN 0974-7907 (online) | 0974-7893 (print)

Editor: Richard Mibey

\section{Manuscript details:}

Ms \# 02059

Received 13 September 2008

Final received 10 October 2009

Finally accepted 23 February 2010

Citation: Hosagoudar, V.B. \& G.R. Archana (2010). Meliolaceae of Kerala India - XXXI new species and a new variety. Journal of Threatened Taxa 2(5): $889-891$

Copyright: ( ) V.B. Hosagoudar \& G.R. Archana 2010. Creative Commons Attribution 3.0 Unported License. JoTT allows unrestricted use of this article in any medium for non-profit purposes, reproduction and distribution by providing adequate credit to the authors and the source of publication.

Acknowledgement: We thank Dr. S. Ganeshan, Director, Tropical Botanic Garden and Research Institute, Palode, Thiruvananthapuram, Kerala for the facilities. We are grateful to Forest Department, Govt. of Kerala for the forest permission.

\section{OPEN ACCESS | FREE DOWNLOAD @C (i) ৫}

branching opposite at acute to wide angles, loosely to closely reticulate, cells $12-30 \times 4-8 \mu \mathrm{m}$. Appressoria alternate, unilateral, $1 \%$ opposite, antrorse to subantrorse, straight, 12-22 $\mu \mathrm{m}$ long; stalk cells cylindrical to cuneate, 3-10 $\mu \mathrm{m}$ long; head cells ovate, oblong, globose, entire to slightly angular, 8-13 x 8-11 $\mu \mathrm{m}$. Phialides mixed with appressoria, opposite to alternate, ampulliform, 12-22 x 6-8 $\mu \mathrm{m}$. Perithecia scattered, globose, up to $145 \mu \mathrm{m}$ in diameter; perithecial cells mammiform, obtuse at the tip, up to $10 \mu \mathrm{m}$ long; ascospores obovoidal, 4-septate, constricted at the septa, 35-42 x 12-18 $\mu \mathrm{m}$.

Based on the digital formula 3101.4220 , it can be compared with Asteridiella glabra (Berk. \& Curt.) Hansf. and Asteridiella uncariicola Hansf. It differs from the former species in having straight and loosely reticulate hyphae and differs from the latter species in having shorter with only entire head cells of the appressoria (Hansford 1961).

\section{Irenopsis kleinhoviae sp. nov.}

(Fig. 2)

\section{Material examined}

24.iv.2007, on leaves of Kleinhovia hospita L. (Sterculiaceae), Karimancode, Thiruvananthapuram, Kerala, India, coll. G.R. Archana, HCIO 48166 (type), TBGT 2902 (isotype), (MycoBank \# 518399).

Coloniae amphigenae, subdensae, ad 5mm diam., confluentes. Hyphae subrectae vel undulatae, opposite, alternate acuteque vel laxe ramosae, laxe vel arte reticulatae, cellulae 16-40 x 4-7 $\mu \mathrm{m}$. Appressoria alternata, unilateralis, antrorsa, subantrorsa vel retrorsa, recta vel curvula, 12-23 $\mu \mathrm{m}$ longa; cellulae basilares cylindraceae vel cuneatae, 3-11 $\mu \mathrm{m}$ longae; cellulae apicales globosae, ovatae, oblongae, integraevel angularis, 8-14x 8-11 $\mu \mathrm{m}$. Phialides appressoriis

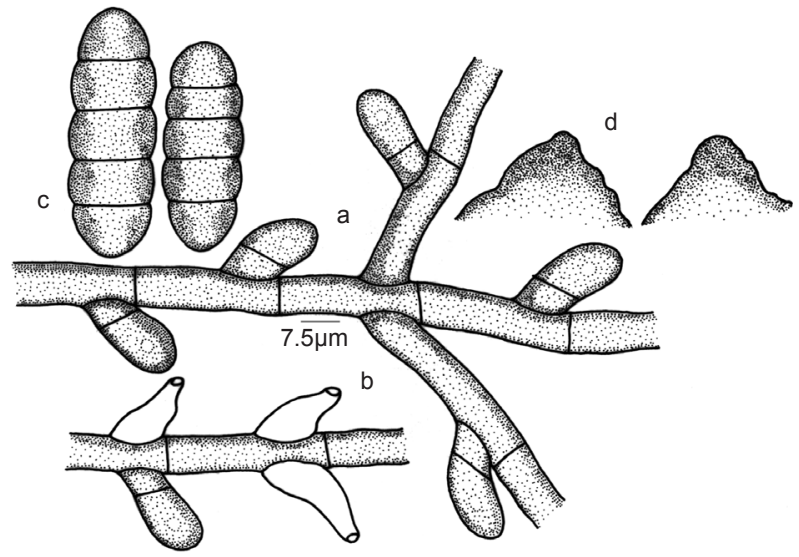

Figure 1. Asteridiella ixorae sp. nov.

a -Appressorium; b - Phialide; c - Ascospores; $d$ - Perithecial wall cells 


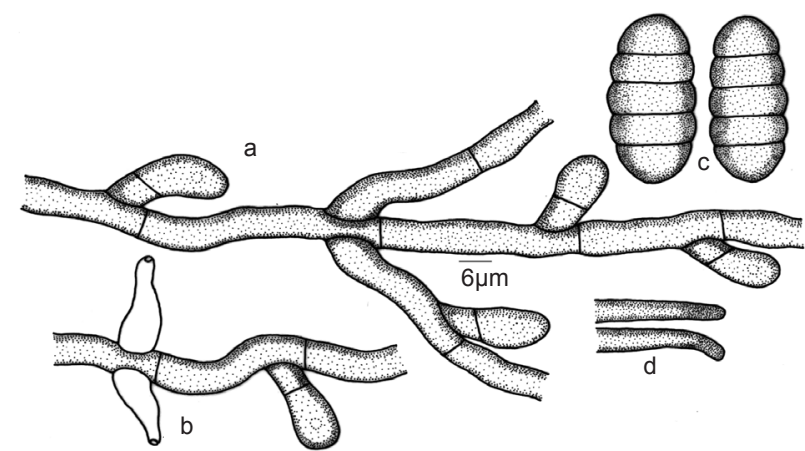

Figure 2. Irenopsis kleinhoviae sp. nov.

a - Appressorium; b - Phialide; c - Ascospores; $d$ - Apical portion of the perithecial setae

intermixtae, oppositae vel alternatae, ampulliformes, 12$24 \times 4-8 \mu \mathrm{m}$. Perithecia globosa, dispersa vel aggregata, ad $130 \mu \mathrm{m}$ diam.; setae peritheciales 4-10 numero, simplices, rectae, pallid brunneae, septatae, ad apicem rectae, uncinatae et obtusae, ad $145 \mu \mathrm{m}$ longae, parietus glabrus; ascosporae obovoideae, 4-septatae, leniter constrictus ad septatae, 32-43 x 11-18 $\mu \mathrm{m}$.

Colonies amphigenous, subdense, up to $5 \mathrm{~mm}$ in diameter, confluent. Hyphae substraight to undulate, branching opposite, alternate at acute to wide angles, loosely to closely reticulate, cells $16-40 \times 4-7 \mu \mathrm{m}$. Appressoria alternate, unilateral, antrorse, subantrorse to retrorse, straight to curved, $12-23 \mu \mathrm{m}$ long; stalk cells cylindrical to cuneate, 3-11 $\mu \mathrm{m}$ long; head cells globose, ovate, oblong, entire to angular, 8-14 x 8-11 $\mu \mathrm{m}$. Phialides mixed with appressoria, opposite to alternate, ampulliform, $12-24 \times 4-8 \mu \mathrm{m}$. Perithecia globose, scattered to grouped, up to $130 \mu \mathrm{m}$ in diameter; perithecial setae 4-10 in number, simple, straight, pale brown, septate, straight to uncinate at the apical part, obtuse at the tip, up to $145 \mu \mathrm{m}$ long, smooth; ascospores obovoidal, 4-septate, slightly constricted at the septa, $32-43 \times 11-18 \mu \mathrm{m}$.

Irenopsis buettneriicola Deight. known on Buettneria sp. and Sterculia sphanoghei from Sierra Leone and Java having both straight and uncinate perithecial setae. However, Irenopsis kleinhoviae differs from it in having pale brown, smooth walled perithecial setae and shorter appressoria having entire head cells.

\section{Meliola ebeni sp. nov.}

(Fig. 3)

\section{Material examined}

10.ix.2006, on leaves of Diospyros ebenum Koenig (Ebenaceae), TBGRI Campus, Thiruvananthapuram, Kerala, India, coll. G.R. Archana et al. HCIO 48167 (type), TBGT 2903 (isotype), (MycoBank \# 518400).

Coloniae amphigenae, subdensae, ad $2 \mathrm{~mm}$ diam., confluentes. Hyphae subrectae vel anfractuae, opposite vel irregulariter acuteque vel laxe ramosae, laxe vel arte

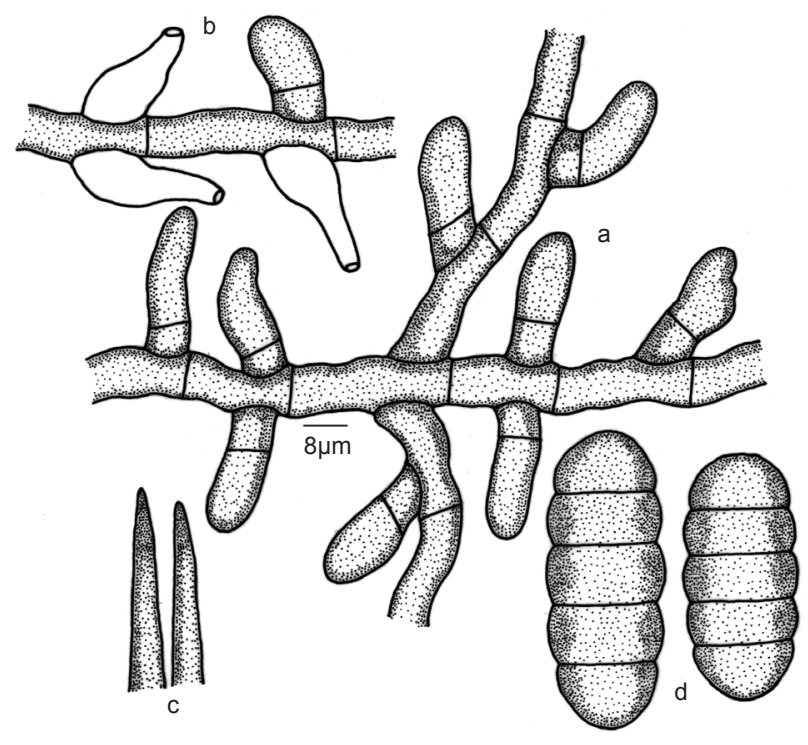

Figure 3. Meliola ebeni sp. nov.

a - Appressorium; b - Phialide; c - Apical portion of the mycelial setae; d - Ascospores

reticulatae, cellulae 12-32 x 4-8 $\mu \mathrm{m}$. Appressoria opposita, alternata, unilateralis, antrorsa, subantrorsa vel retrorsa, recta vel curvula, 11-26 $\mu \mathrm{m}$ longa; cellulae basilares cylindraceae vel cuneatae, 3-8 $\mu \mathrm{m}$ longae; cellulae apicales oblongae, ovatae, cylindraceae, globosae, rectae vel varie curvulae, integrae vel angularis, 8-18 x 6-15 $\mu \mathrm{m}$. Phialides appressoriis intermixtae, oppositae vel alternatae, ampulliformes, 16-24 x6-8 $\mu \mathrm{m}$. Setae myceliales simplices, rectae, ad apicem acutae, ad $490 \mu \mathrm{m}$ longae. Perithecia dispersa vel aggregata, ad $160 \mu \mathrm{m}$ diam.; ascosporae obovoideae, 4-septatae, leniter constrictus ad septatae, 38-45 x 12-16 $\mu \mathrm{m}$.

Colonies amphigenous, subdense, up to $2 \mathrm{~mm}$ in diameter, confluent. Hyphae substraight to crooked, branching opposite to irregular at acute to wide angles, loosely to closely reticulate, cells $12-32 \times 4-8 \mu \mathrm{m}$. Appressoria opposite, alternate, unilateral, antrorse, subantrorse to retrorse, straight to curved, 11-26 $\mu \mathrm{m}$ long; stalk cells cylindrical to cuneate, 3-8 $\mu \mathrm{m}$ long; head cells oblong, ovate, cylindrical, globose, straight to variously curved, entire to angular, 8-18 x 6-15 $\mu \mathrm{m}$. Phialides mixed with appressoria, opposite to alternate, ampulliform, 16$24 \times 6-8 \mu \mathrm{m}$. Mycelial setae, simple, straight, acute at the tip, up to $490 \mu \mathrm{m}$ long. Perithecia scattered to grouped, up to $160 \mu \mathrm{m}$ in diameter; ascospores obovoidal, 4-septate, slightly constricted at the septa, 38-45 x 12-16 $\mu \mathrm{m}$.

Crooked mycelium with variously curved appressoria with cylindrical to oblong head cells distinguishes this species from rest of the Meliola species known on the members of the family Ebenaceae (Hansford 1961; Hosagoudar et al. 1997; Hu et al. 1997, 1999; Hosagoudar 2008; Hosagoudar \& Agarwal 2008). 


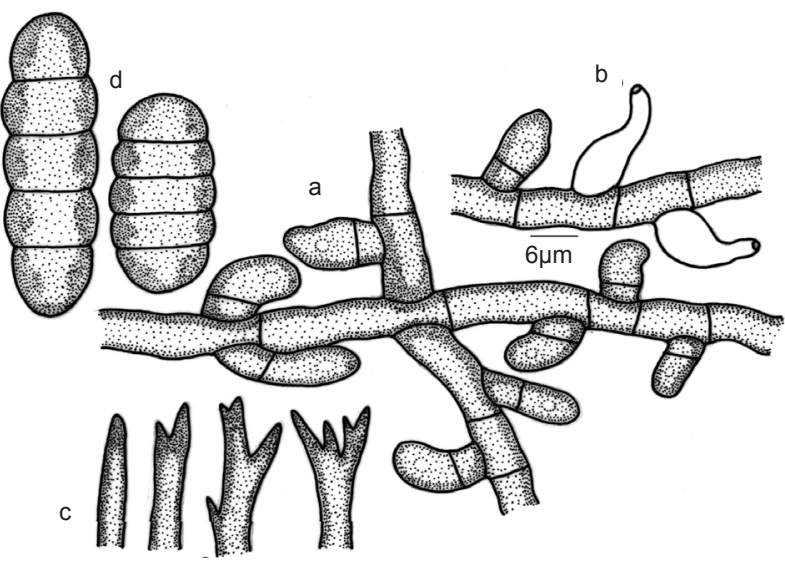

Figure 4. Meliola filicii Hosag. var. indica var. nov. a - Appressorium; b - Phialide; c - Apical portion of the mycelial setae; d - Ascospores

\section{Meliola filicii Hosag. var. indica var. nov.} (Fig.4)

\section{Material examined}

20.ii.2007, on leaves of Filicium decipiens (Wight \& Arn.) Thw. (Sapindaceae), Ponmudi, Thiruvananthapuram, Kerala, India, coll. G.R. Archana et al. HClO 48168 (type), TBGT 2904 (isotype), (MycoBank \# 518401).

Differt a var. filicii setae myceliales ad apicem denatae vel furcatae.

Colonies hypophyllous, dense, up to $2 \mathrm{~mm}$ in diameter, confluent. Hyphae straight to substraight, branching opposite alternate at acute to wide angles, loosely to closely reticulate, cells 11-24 x 4-7 $\mu \mathrm{m}$. Appressoria opposite alternate, antrorse, subantrorse to retrorse, 8-15 $\mu \mathrm{m}$ long; stalk cells cylindrical to cuneate, 2-6 $\mu \mathrm{m}$ long; head cells ovate, globose, entire to angular, straight to curved, 6-11 x 6-8 $\mu \mathrm{m}$. Phialides few, mixed with appressoria, opposite to alternate, ampulliform, 9-16 x 4-7 $\mu \mathrm{m}$. Mycelial setae simple, straight, acute, dentate to furcate at the tip, up to $350 \mu \mathrm{m}$ long. Perithecia scattered to grouped, up to $196 \mu \mathrm{m}$ in diameter; ascospores obovoidal, 4-septate, slightly constricted at the septa, 25-37 x 8-13 $\mu \mathrm{m}$.

The new variety differs from the variety filicii in having only dentate to furcate apical tip of the mycelial setae (Hosagoudar 1996).

\section{REFERENCES}

Hansford, C.G. (1961). The Meliolaceae. A Monograph. Sydowia Beih 2: 1-806.

Hosagoudar, V.B. (1996). Meliolales of India. Botanical Survey of India, Calcutta, 363pp.

Hosagoudar, V.B., T.K. Abraham \& P. Pushpangadan (1997). The Meliolineae - A Supplement. Tropical Botanic Garden and Research Institute, Palode, Thiruvananthapuram, Kerala, India, 201pp.

Hosagoudar, V.B. (2008). Meliolales of India. Vol. II. Botanical Survey of India, Kolkota.

Hosagoudar, V.B. \& D.K. Agarwal (2008). Taxonomic studies of Meliolales. Identification Manual. International Book Distributors, Dehradun, 263pp.

Hu, Y., Y. Ouyang, S. Bin G. Jiang (1996). Flora Fungorum Sinicorum. Vol. 4. Meliolales (1). Science Press Beijing, 270pp+IVpls.

Hu, Y., S. Bin, Y. Ouyang \& G. Jiang (1999). Flora Fungorum Sinicorum. Vol. 11. Meliolales (2). Science Press Beijing, 252pp. 